\title{
The Mediating Role of Affective Commitment in Perceived Organizational Support and Readiness for Change
}

\section{Artisita Rochmi ${ }^{a}$ and Arum Etikariena Hidayat ${ }^{\mathrm{b}}$}

${ }^{a}$ Faculty of Psychology, Universitas Indonesia, Depok, Indonesia; ${ }^{b}$ Department of Industrial and Organizational Psychology, Faculty of Psychology, Universitas Indonesia, Depok, Indonesia

*Corresponding author:

Arum Etikariena Hidayat

Department of Industrial and Organizational Psychology

Faculty of Psychology, Universitas Indonesia

J1. Lkr. Kampus Raya, Depok, Jawa Barat

Indonesia, 16424

Tel.: +62 217270004

Email address: arum.etikariena@ui.ac.id / arum.hidayat@gmail.com 


\title{
The Mediating Role of Affective Commitment in Perceived Organizational Support and Readiness for Change
}

\begin{abstract}
The study aimed to explore the relationship between perceived organizational support and readiness for change mediated by affective commitment. The empirical data was collected from 144 non-probability convenient samples of the government employees from various levels and positions. Readiness for change was measured using the Readiness for Change Scale, how much support employees felt they got from their organization was assessed using the Survey of Perceived Organizational Support, and an Affective Commitment subscale was used to measure employees' affective commitment. The study results showed that perceived organizational support improves employee readiness for change as a consequence of the mediation of affective commitment. Employees who perceive their organization as supportive will have a higher positive emotional attachment to the organization and a more positive response to the change process in their organization. Additionally, this paper discusses the theoretical and methodological implications of these findings and offers direction for the future research in this area.
\end{abstract}

Keywords: perceived organizational support, readiness for change, affective commitment

\section{Introduction}

To remain effective, all organizations must continually improve (Immordino, 2014). This applies to public sector organizations as well. Government employees at all levels are subject to the internal and external pressures that demand change. One of the significant changes in public institutions is the government effort to minimize corruption. Institution $\mathrm{X}$ is responsible for minimizing the illegal use of controlled substances through a preventive program and law enforcement referrals (National Narcotics Board Republic of Indonesia official website, 2018). At the time of the study, this institution employed 4.843 civil-service employees, 36,5\% (1,766 people) of whom were also members of the Indonesian National Police force. Five members of the Indonesian National Army also worked at Institution X (National Narcotics Board Republic of Indonesia, 2018).

After the issuance of Government Regulation No. 11 of 2017, all public institution implemented open selection for top management positions. Because of this, employees no longer need a long service record to be promoted. Employees who passed a competency test are eligible to fill a position regardless of their tenure seniority level. This regulation promised greater transparency for management processes.

More than $20 \%$ of the line management at Institution X have a military background. This change was implemented in a considerably short period. The average frequency of leadership changes in structural position in the last five years (2014-2018) is more than $60 \%$, while the job rotation in general increases more than 40\% (National Narcotics Board Republic of Indonesia official personnel management information system website, 2018). 
In 2014, the Indonesian government issued act No. 5 about Aparatur Sipil Negara. This regulation encouraged government employees to become agents of change in the context of the bureaucratic reforms aimed towards professional governance and support for technological innovation. Consequently, Institution $\mathrm{X}$ has implemented more effective and efficient work methods. Employees have become involved in new programs financed by new funding sources, and they are compelled to take part in new work arrangements.

Fontaine, Haarman, and Schmid (2006) emphasized that organizational change occurs at various levels to increase organizational effectiveness. For the public service process to not be negatively affected by rapid change, organizations must ensure that employees are well prepared to deal with change. Readiness for change (RFC) has been defined as "a comprehensive attitude that is influenced simultaneously by the content (i.e., what is being changed), the process (i.e., how the change implemented), the context (i.e., circumstances under which the change is occurring), and the individuals (i.e., characteristics of those being asked to change) involved." (Holt, Armenakis, Harris, \& Feild, 2007, pp. 235.) RFC is reflected in employees' beliefs, attitudes, and intentions regarding the level of change needed and the organization's capacity to implement it successfully (Armenakis, Harris, \& Mossholder, 1993).

Perceived organizational support (POS) is the extent to which employees feel that their organization values their contributions, cares about their well-being, and fulfills their needs. Previous research has found that employees' POS levels can be used to predict RFC (Eby, Adams, Russell, \& Gaby, 2000). Employees who perceived their work environment as providing high levels of support reported also reported high levels of RFC (Weber \& Weber, 2001). According to Allen \& Meyer (1990), when the employees gave their organization a high POS score, it was an indication of their feeling that the organization valued their contribution. These employees felt their well-being was taken into consideration and their efforts were appreciated. Supportive organizations were also evaluated as caring about employees' general work satisfaction and having a willingness to respond to employee complaints. When employees perceive their organization as supportive, they pay attention to the need for changes in the organization/ and they have a willingness to follow through on those changes. However, employees will only support changes they consider to be legitimate and rational (Self, Armenakis, \& Schraeder, 2007). According to Ming-Chu and Meng-Hsiu (2015), POS has a significant relationship with RFC in employees. The employees with high POS scores will be the ones who are best prepared to deal with organizational change (Madsen, Miller, \& John, 2005).

Employee POS is characterized by a belief that the organization intends to promote a conducive work environment that supports employee welfare (Eisenberger, Huntington, Hutchison, \& Sowa, 1986). The POS requires significant input from tan organization to trigger social exchange in the workplace so that employees are willing to participate actively and support the organizational change (Rhoades, \& Eisenberger, 2002). When employees feel supported by their organization, they are much more likely to believe that the company cares about their well-being (Self, Armenakis, \& Schraeder, 2007). Since employee attitudes, beliefs, behaviors, and 
intentions are a necessary component of organizational change (French, Bell, \& Zawacki, 2004), we can propose that POS is positively related to RFC.

$\mathrm{AC}$ is described as the strength of identification, emotional attachment, and involvement that employees have for their organization (Neves, 2009). This particular dimension of organizational commitment has been hypothesized to be strongly related to various critical organizational phenomena, such as rotation and various aspects of negative, including refusing to adapt to change. Research by Kwahk \& Lee shows that committed employees are more ready and actively involved in an organizational change initiative. This result underscores the fact that committed employees are a crucial resource to ensure that ongoing changes do not negatively affect the overall functioning of an organization (Kwahk, \& Lee, 2008). An employee with high $\mathrm{AC}$ would feel as if their organization's problems were their own and that their organization is a part of their family. Additionally, they feel emotionally attached to the organization and would be glad to spend the rest of their career there because the organization has a great deal of personal meaning for them (Eisenberger, Huntington, Hutchison, \& Sowa, 1986). Moreover, employees with strong AC see value in change initiatives, and they are willing to do what the organization asks of them, such as extra work, and engage in activities to ensure successful change.

AC plays a vital role in accepting, behaving, and reacting positively to organizational change. A person with a high organizational commitment is gladder to accept organizational change (Morin, Meyer, Bélanger, Boudrias, Gagné, \& Parker, 2015). Additionally, they want to make more effort on behalf of the organization. The committed employee feels psychologically bound to and identified with their organization, and they internalize the organization's values and goals (Meyer \& Allen, 1997). Employees who have a stronger commitment to the organization will be more likely to be involved in pro-change behavior and tend not to be involved in anti-change behavior (Peccei, Giangreco, \& Sebastiano, 2011). Moreover, individuals with a high affective commitment have also been shown to have a more positive view of organizational events and their work environment compared to individuals with a lower affective commitment level (Meyer \& Allen, 1997). Recent research in a sustainable specific environment has explored how POS influences employees' pro-environmental behavior at work (Paillé, \& Raineri, 2015). Another study in organizational behavior shows that POS increases commitment to fellow employees, which in time affects job performance, group cohesion, and extra-role behavior (Bishop, Scott, \& Burroughs, 2000). An organization's efforts to make their employees realize that they are appreciated results in higher levels of employee AC, because when employees have a sense of organizational support, they will make extra efforts to reach organizational goals (Muneer, Iqbal, Khan, \& Long, 2014).

The positive association between POS and RFCis well-documented in the literature. (Ming-Chu \& Meng-Hsiu, 2015; Aarons, Ehrhart, Farahnak, \& Hurlburt, 2015; Buick, Blackman, O’Donnell, O’Flynn, \& West, 2015; Fuchs \& Prouska, 2014; Heyden, Fourné, Koene, Werkman, \& Ansari, 2017; Kirrane, Lennon, O’Connor, \& Fu, 2016). The relationship between AC and RFC been found to be significant as well (Morin et al., 2015; Malik, \& Garg, 2017; Shin, Seo, Shapiro, \& Taylor, 2015). 
An organization such as Institution $\mathrm{X}$, which tends to experience rapid internal changes is a perfect environment for examining how POS and AC play a role in employees' readiness for organizational change. However, previous studies have not included AC as an aspect of the POS-RFC relationship, leaving a gap which invites further investigation. Therefore, this research aims to integrate the relationships among these variables.

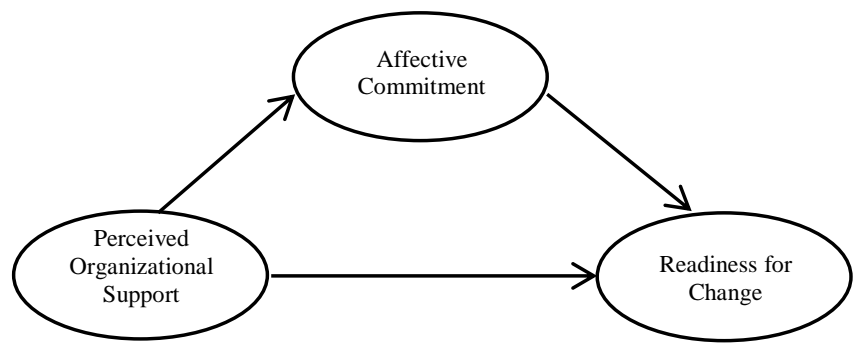

Fig. 1. POS - AC - RFC Mediation Model

\section{Methods}

\section{Participants}

The data was collected from participants working in 39 different work units in 19 different Indonesian provinces to ensure having a representative sample of diverse work environments. An online and paper-based questionnaire was sent to various governments' employees. There was a total of 144 respondents who had worked for Institution $\mathrm{X}$ for at least a year. Sixty-eight percent of the participants were female, and $32 \%$ were male. The ages of the participants ranged from 23 to 57 years old $(M=34.38, S D=6.49)$, their length of employment extended from 1 to 35 years $(\mathrm{M}=8.17, \mathrm{SD}=6.53)$. The participants' education level varied from bachelor's degree (70.83\%), master's degree $(13.19 \%)$, other diploma (9.03\%), to high school graduate $(6.94 \%)$. The participants' job status was categorized as functional (50\%), general functional $(36.11 \%)$, or managerial $(14.58 \%)$.

\section{Research Design and Procedure}

This research took the form of a cross-sectional design using quantitative methods. The variables included POS (independent variable), RFC (dependent variable), and affective commitment level (mediator variable). The sampling technique was non-probability convenient sampling. The study questionnaire was a self-report survey consisting of three measurement instruments adapted and administered in Bahasa Indonesia. The respondents were also asked to provide demographic data consisting of age, gender, work tenure, educational background, and employment level.

The survey was posted on various social media websites with a link to an online web-hosted survey. Out of the 50 online questionnaires received, only 44 were included in the analysis. The researcher also distributed 120 paper-based questionnaires to participants, of which 100 copies were completed and returned, for a response rate of $84.70 \%$. 


\section{Measurement Instruments}

POS was assessed using the Survey of Perceived Organizational Support (Eisenberger, Huntington, Hutchison, \& Sowa, 1986) adapted from Baliartati (2016). The survey consists of eight items, which use a six-point Likert scale for respondents to indicate how much they agreed with each statement). A higher score indicates a higher level of employee POS. The internal consistency for the survey using Cronbach's $\alpha$ was 0.71 .

The Readiness for Change Scale (Hanpachern, 1997) adapted by Yuniarti (2017) was used to measure employees' RFC. The scale has fifteen items about the respondents' "willingness to be a part of a change program." Items are answered using a six-point Likert scale ranging from 1 ('strongly disagree') to 6 ('strongly agree'). High scores on the scale are indicative of a high level of change readiness. The internal consistency for the RFC Scale using Cronbach's $\alpha$ was 0.83 .

The Affective Commitment Subscale of the Commitment Scale (Allen, \& Meyer, 1990) adapted by Ersya (2016) was used to assess the employees' degree of affective commitment. The subscale consists of six items regarding being happy to spend the rest one's my career with one's organization. Respondents reported their level of agreement on each item by making a choice on a 6-point Likert scale ( $1=$ strongly disagree, $6=$ strongly agree). The internal consistency for the AC Scale using Cronbach's $\alpha$ was 0.74 .

\section{Data Analysis}

Descriptive statistics were performed to explore the respondents' demographic data. The Pearson product moment correlation coefficient was used to analyze the correlation between variables. A simple mediation model was run in SPSS 24.0 to test the research hypothesis.

\section{Results}

\section{Descriptive Statistics and Correlations}

The researchers wanted to ascertain whether demographic variables had a significant relationship with employee readiness for change. Table 1 summarizes the statistical analysis results. 
Table I. Means, Standard Deviations, and Correlations for the Study Variables

\begin{tabular}{|c|c|c|c|c|c|c|c|c|c|c|c|}
\hline & $\mathbf{M}$ & SD & 1 & 2 & 3 & 4 & 5 & 6 & 7 & 8 & 9 \\
\hline 1 Level & 1,15 &, 35 & 1 & & & & & & & & \\
\hline 2 Gender &, 32 & ,47 & ,077 & 1 & & & & & & & \\
\hline $\begin{array}{l}3 \text { Work } \\
\text { tenure }\end{array}$ & 1,46 &, 50 &, $488^{* *}$ &,- 062 & 1 & & & & & & \\
\hline 4 Education & 1,18 & ,69 &, $303 * *$ & , 146 &, $246 * *$ & 1 & & & & & \\
\hline 5 Age & 1,33 &, 52 &, $268 * *$ & 055 &, $252 * *$ &, $265 * *$ & 1 & & & & \\
\hline 6 Work unit & 1,40 &, 49 &,$- 249 * *$ &,- 006 &, $488 * *$ &,- 131 &,- 013 & 1 & & & \\
\hline 7 RFC & 4,72 &, 07 &,$- 233 * *$ &,$- 169 *$ &, $404 * *$ &,- 001 &,- 140 &, $508 * *$ & 1 & & \\
\hline 8 POS & 3,87 &, 11 &,- 076 & , 151 &, $265^{* *}$ &,- 003 & ,025 &, $411 * *$ &, $755^{* *}$ & 1 & \\
\hline \multicolumn{12}{|l|}{9 Affective } \\
\hline commitment & 4,75 &, 12 &,- 029 &, $174 *$ &, $215^{* *}$ & ,038 &,- 009 &, $297 * *$ &, $825 * *$ &, $790 * *$ & 1 \\
\hline
\end{tabular}

As Table 1 shows, two of the demographic variables in this study have a significant correlation with RFC--work tenure $(\mathrm{R}=-.02, \mathrm{p}<01)$ and work units $(\mathrm{R}=.03, \mathrm{p}<.01)$. Therefore, these two variables are included in the analysis as controls. Additionally, Table 1 shows that POS and RFC have a positive and significant correlation. This pattern of relationship is also shown between AC and RFC and POS and AC.

\section{Mediation Analysis}

Although POS is positively related to RFC (Buick, Blackman, O'Donnell, O'Flynn, \& West, 2015) whether AC mediates that relationship has not yet been clarified. According to Bakari, Hunjra, \& Niazi, looking at affective commitment as a mediator in the POS-RFC relationship is recommended to improve understanding of the mechanisms through which organizational support influences the change process (Bakari, Hunjra, \& Niazi, 2017). Testing whether AC played a role as a variable mediator in the POS-RFC relationship, a mediation analysis was used (Hayes, 2013). The hypothesis that AC mediates the effects of POS on RFC, was supported $($ Effect $=.29, \mathrm{SE}=.06, \mathrm{CI}[.18, .42])$. The indirect effect significance used 10,000 bootstrap samples. Figure 2 shows the estimated coefficients between each path in the model.

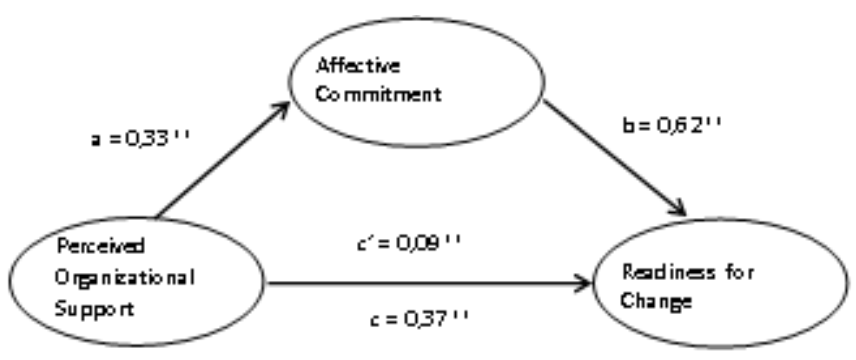

Fig. 2. Statistical Model of Affective Commitment as a Mediator in Perceived Organizational Support and Readiness for Change 


\section{Discussion and Conclusion}

We inferred from the results of the mediation analysis, that there is a mediation role of affective commitment in the relationship between POS and RFC (Figure 2). This result is supported in several previous studies that mention AC as the mediator between POS and RFC relationship.

POS has a positive and significant relationship with RFC. This result shows that the higher the POS by an employee, the higher the employee's RFC. When employee POS is high, they believe that the organization cares about and respects them, the employees will support an organization's change programs as long as the reason for the change is legitimate and rational (Self, Armenakis, \& Schraeder, 2007). This is also supported by Ming-Chu \& Meng-Hsiu (2015) research, which found that POS has a significant effect on RFC. When the employee POS levels are high, they will have better resources to deal with organizational changes.

We concluded that there is a significant positive relationship between POS and AC. In other words, when employees are treated well, they will have a more positive approach and a deeper commitment to their work organization [22]. This result is congruence with the idea that more an organization supports its employees, the more the emotionally invested the employees will be. Third, the results of the study show that affective commitment is significantly related to readiness for change. Meyer \& Allen stated that individuals who are very committed to the organization tend to see the work environment more positive contrasted with a lower level of commitment (Meyer, \& Allen, 1997). Hence, those with the higher level of commitment expected to have a friendlier attitude and more positive perceived organizational support towards change, regardless of their impression on change benefits and their actual involvement in the change process.

Fourth, affective commitment acts as a mediator in the relationship between perceived organizational support and readiness for change. The existence of affective commitment can mediate the effect of the perceived organizational support towards readiness for change. The employee who perceived the organization well supports them has a higher positive emotional attachment to the organization, which then results in more positive responses toward the change process in their organization.

The conclusion of this study shows that AC mediates the relationship between POS and RFC. This result shows that POS not only affect RFC directly but also indirectly through AC. The POS received by employees in the workplace will make employees feel that the organization highly respects [11] and pays attention to every employee's effort (Kwahk \& Lee, 2008) and their achievement and the organization pay attention to employees' complaints (Eisenberger, Huntington, Hutchison, \& Sowa, 1986). Support provided by the organization will run more effectively (Muneer, Iqbal, Khan, \& Long, 2014) if the employee has an affective commitment in each process so that later it will make employees have the readiness to face organizational changes (Kwahk \& Lee, 2008). If POS in the workplace is applied by increasing AC, the employee will increase RFC further. The results of this study point to increasing organizational 
support to increase employees' levels of commitment to the organization and to improve employee readiness to follow through on organizational changes (DeConinck \& Johnson, 2009)

This study would benefit from in-depth qualitative analysis to ascertain more about employees sociopsychological connections with their organizations. Qualitative methods may elicit specific recommendations for organizational change. A longitudinal research design is suggested for future study to explore how affective commitment develops over time.

\section{References}

Armenakis, A., Harris, S., \& Mossholder, K. (1993). Creating readiness for organizational change. Human Relations, 46, 681-703. 10.1177/001872679304600601

Allen, N., \& Meyer, J. (1990). The measurement and antecedents of affective, continuance and normative commitment to the organization. Journal of Occupational Psychology, 63, 1-18. 10.1111/j.20448325.1990.tb00506.x

Aarons, G., Ehrhart, M., Farahnak, L., \& Hurlburt, M. (2015). Leadership and organizational change for implementation (LOCI): A randomized mixed method pilot study of a leadership and organization development intervention for evidence-based practice implementation. Implementation Science, 10. 10.1186/s13012-014-0192-y

Bakari, H., Hunjra, A., \& Niazi, G. (2017). How does authentic leadership influence planned organizational change? The role of employees' perceptions: integration of theory of planned behavior and lewin's three step model. Journal of Change Management, 17, 155-187. 10.1080/14697017.2017.1299370

Bishop, J., Scott, K., \& Burroughs, S. (2000). Support, commitment, and employee outcomes in a team environment. Journal of Management, 26, 1113-1132. 10.1177/014920630002600603

Buick, F., Blackman, D., O’Donnell, M., O’Flynn, J., \& West, D. (2015). Can enhanced performance management support public sector change?. Journal of Organizational Change Management, 28, 271-289. 10.1108/jocm-12-2013-0249

Baliartati, B.O. (2016). Pengaruh Organizational Support Terhadap Job Satisfaction Tenaga Edukatip Tetap Fakultas Ekonomi dan Bisnis Universitas Trisakti. Jurnal Manajemen dan Pemasaran Jasa, 9, 35-52.

Cropanzano, R., \& Mitchell, M. (2005). Social exchange theory: An interdisciplinary review. Journal of Management, 31, 874-900. 10.1177/0149206305279602

DeConinck, J., \& Johnson, J. (2009). The effects of perceived supervisor support, organizational justice on turnover among salespeople. Journal of Personal Selling \& Sales Management, 29, 333-350. $10.2753 /$ pss0885350

Dinc, E. (2015). Perceived organizational support as a mediator of the relationship between effort-reward fairness, affective commitment, and intention to leave. International Business Research, 8, 259-269. $10.5539 /$ ibr.v8n4p259

Ersya, C. (2016). Pengaruh General Self-Efficacy dan Organizational Mobility Preferences Terhadap Komitmen Afektif (Unpublished Undergraduate mini thesis). Universitas Indonesia, Depok, Indonesia.

Eisenberger, R., Huntington, R., Hutchison, S., \& Sowa, D. (1986). Perceived organizational support. Journal of Applied Psychology, 71, 500-507. 10.1037/0021-9010.71.3.500

Eby, L., Adams, D., Russell, J., \& Gaby, S. (2000). Perceptions of organizational readiness for change: Factors related to employees' reactions to the implementation of team-based selling. Human Relations, 53, 419442. 10.1177/0018726700533006

French, W., Bell, C., \& Zawacki, R. (2004). Organization development and transformation: Managing effective change. New York: McGraw-Hill.

Fontaine, C., Haarman, A., \& Schmid, S. (2006). The Stakeholder Theory. Retrieved from https://pdfs.semanticscholar.org/ 
Fuchs, S., \& Prouska, R. (2014). Creating positive employee change evaluation: The role of different levels of organizational support and change participation. Journal of Change Management, 14, 361-383. 10.1080/14697017.2014.885460

Immordino, K. M. (2014). Organizational Assessment and Improvement in The Public Sector Workbook. Boca Raton: CRC Press.

National Narcotics Board Republic of Indonesia official website. (2018). Retrieved from http://bnn.go.id

National Narcotics Board Republic of Indonesia official personnel management information system website. (2018). Retrieved from http://simpeg.bnn.go.id

Holt, D., Armenakis, A., Harris, S., \& Feild, H. (2007). Toward a comprehensive definition of readiness for change: A review of research and instrumentation. Research in Organizational Change and Development, $16,289-336$

Heyden, M., Fourné, S., Koene, B., Werkman, R., \& Ansari, S. (2017). Rethinking “top-down” and "bottom-up" roles of top and middle managers in organizational change: Implications for employee support. Journal of Management Studies, 54, 961-985. 10.1111/joms.12258

Hanpachern, C. (1997). The extension of the theory of margin: A framework for assessing readiness for change (Unpublished Doctoral Dissertation). Colorado State University, Fort Collins.

Hayes, A. F. (2013). Introduction to mediation, moderation, and conditional process analysis: A regression-based approach. New York, NY: Guilford Press.

Kwahk, K.Y. \& Lee, J.N. (2008). The role of readiness for change in ERP implementation: Theoretical bases and empirical validation. Journal of Information \& Management, 45, 474-481. 10.1016/j.im.2008.07.002

Kirrane, M., Lennon, M., O’Connor, C., \& Fu, N. (2016). Linking perceived management support with employees' readiness for change: The mediating role of psychological capital. Journal of Change Management, 17, 47-66. 10.1080/14697017.2016.1214615

Ming-Chu, Y., \& Meng-Hsiu, L. (2015). Unlocking the black box: Exploring the link between perceive organizational support and resistance to change. Asia Pacific Management Review, 20, 177-183. 10.1016/j.apmrv.2014.10.003

Madsen, S., Miller, D., \& John, C. (2005). Readiness for organizational change: Do organizational commitment and social relationships in the workplace make a difference? Human Resource Development Quarterly, 16, 213-234. 10.1002/hrdq.1134

Morin, A., Meyer, J., Bélanger, É., Boudrias, J., Gagné, M., \& Parker, P. (2015). Longitudinal associations between employees' beliefs about the quality of the change management process, effective commitment to change and psychological empowerment. Human Relations, 69, 839-867. 10.1177/0018726715602046

Meyer, J. \& Allen, N. (1997). Commitment in the Workplace: Theory, Research, and Application. Thousand Oaks, CA: SAGE Publications, Inc. 10.4135/9781452231556

Muneer, S., Iqbal, S., Khan, S., \& Long, C. (2014). An incorporated structure of perceived organizational support, knowledge-sharing behavior, organizational trust and organizational commitment: A strategic knowledge management approach. Pakistan Journal of Commerce and Social Sciences, 8, 42-57.

Malik, P., \& Garg, P. (2017). The relationship between learning culture, inquiry and dialogue, knowledge sharing structure and affective commitment to change. Journal of Organizational Change Management, 30, 610631. 10.1108/jocm-09-2016-0176

Neves, P. (2009). Readiness for change: Contributions for employee's level of individual change and turnover intentions. Journal of Change Management, 9, 215-231. 10.1080/14697010902879178

Peccei, R., Giangreco, A., \& Sebastiano, A. (2011). The role of organisational commitment in the analysis of resistance to change. Personnel Review, 40, 185-204. 10.1108/00483481111106075

Paillé, P., \& Raineri, N. (2015). Linking perceived corporate environmental policies and employees ecoinitiatives: The influence of perceived organizational support and psychological contract breach. Journal of Business Research, 68, 2404-2411. 10.1016/j.jbusres.2015.02.021

Rhoades, L., \& Eisenberger, R. (2002). Perceived organizational support: a review of the literature. Journal of Applied Psychology, 87, 698-714. 10.1037//0021-9010.87.4.698

Shin, J., Seo, M., Shapiro, D., \& Taylor, M. (2015). Maintaining employees' commitment to organizational change. The Journal of Applied Behavioral Science, 51, 501-528. 10.1177/0021886315603123 
Self, D., Armenakis, A., \& Schraeder, M. (2007). Organizational change content, process, and context: a simultaneous analysis of employee reactions. Journal of Change Management, 7, 211-229. 10.1080/14697010701461129

Yuniarti, W. (2013). Pengaruh Psychological Capital Terhadap Kesiapan Karyawan Untuk Berubah Dengan Intervensi Pelatihan Efikasi Diri dan Resiliensi di PT. X (Master Thesis). Universitas Indonesia, Depok, Indonesia.

Weber, P., \& Weber, J. (2001). Changes in employee perceptions during organizational change. Leadership and Organization Development Journal, 22, 291-300. 10.1108/01437730110403222 